\title{
PERSPEKTIF GENDER DALAM PEMBANGUNAN NASIONAL INDONESIA
}

\author{
Niken Prasetyawati \\ UPT PMK Sosial Humaniora, FBMT, Institut Teknologi Sepuluh Nopember \\ nikenprasetyawati@gmail.com
}

\begin{abstract}
ABSTRAK
Proses pelaksanaan pencapaian tujuan pembangunan berkelanjutan yang tertuang dalam Perpres No.59 tahun 2017 merupakan komitmen pemerintah RI sebagai anggota PBB untuk ikut serta mewujudkan Sustainable Development Goals(SDGs 2017) yang tertuang dalam Transforming Our World: The 2030 Agenda for Sustainable Development. Salah satu tujuan SDGs yang dituangkan dalam Lampiran Perpres No.59 tahun 2017 sebagai tujuan global dan diselaraskan dengan pembangunan nasional Indonesia, adalah jaminan kesetaraan gender dan pemberdayaan perempuan.Kesetaraan gender merupakan hak asasi yang fundamental yang akan mencegah terjadinya perlakuan yang diskriminatif.Kesetaraan gender juga dapat menjadi salah satu cara mencapai pertumbuhan ekonomi, memerangi kelaparan, kemiskinan, pencegahan HIV/AIDS,yang akan diwujudkan dalam agenda pembangunan nasional yang berkelanjutan.Perwujudan kesetaraan gender dan pemberdayaan merupakan wujud komitmen pemerintah bersama negara negara anggota PBB untuk mencapai SDGs yang dimulai tahun 2017.
\end{abstract}

Kata kunci : gender, pembangunan nasional, sustainable development goals.

\section{PENDAHULUAN}

Pembangunan adalah suatu isu penting yang tak pernah berhenti dibicarakan baik itu oleh negara miskin, negara yang sedang berkembang ataupun negara maju. Meskipun konteks yang dibicarakan ataupun cara yang digunakan untuk melaksanakan berbeda beda pada setiap negara. Pembangunan pada hakekatnya adalah suatu upaya terus menerus, yang bersifat sistematis dan terencana secara sebagian ataupun keseluruhan komponen bangsa untuk mengubah suatu keadaan menjadi keadaan yang lebih baik dengan memanfaatkan segala sumber daya yang ada dengan tujuan untuk meningkatkan kesejahteraan dan meningkatkan kualitas hidup manusia dan masyarakat disuatu negara, demikian juga yang dilakukan pemerintah Indonesia. Pembangunan nasional yang dilakukan sejak Indonesia merdeka sampai sekarang ,adalah perwujudan dari amanat dari alinea IV Pembukaan UUD 1945 yaitu :untuk melindungi segenap bangsa dan seluruh tumpah darah Indonesia,memajukan kesejaahteraan umum,mencerdaskan kehidupan bangsa, ikut melaksanakan ketertiban dunia yang berdasarkan atas kemerdekaan, perdamaian abadi dan keadilan sosial.

Pembangunan nasional tidak hanya bertujuan meningkatkan pertumbuhan ekonomi saja ataupun peningkatan pendapatan perkapita tetapi juga diharapkan dapat meningkatkan kualitas semua warganegara yang menjadi bagian penting dari satu negara.Upaya pembangunan nasional suatu negara selalu ditujukan untuk semua penduduk warga dari suatu negara tanpa membedakan jenis kelamin, ras, suku ataupun kelompok agama tertentu, meskipun sering terjadi dalam pelaksanaannya upaya ini menimbulkan dampak ketidak adilan, diskriminasi, ketimpangan sosia dalam masyarakat.

Dalam beberapa dekade mulai timbul dampak pembangunan yang terjadi sebagai akibat pengabaian beberapa hal yang terkait dengan pembangunan seperti misalnya pelaksanaan pembangunan yang tidak memperhatikan kesetaraan gender,pelaksanaan pembangunan yang hanya mengejar peningkatan pertumbuhan ekonomi saja tanpa memperhatikan pemerataan pertumbuhan ekonomi sehingga timbul ketimpangan ketimpangan dalam suatu negara sebagai 
dampak pembangunan yang tidak memperhatikan perspektif gender.Oleh karena itu negara negara dunia yang tergabung dalam PBB (Perserikatan Bangsa Bangsa) bersepakat mencari solusi bersama agar bisa meminimalisir dampak pembangunan yang tidak dikehendaki.

\section{PEMBAHASAN}

\subsection{Konsep Pembangunan Nasional}

Saat ini istilah pembangunan banyak digunakan dan diartikan secara berbeda sesuai dengan pemahaman mengenai pembangunan dan perubahan social, dan banyak digunakan istilah pembangunan terutama apabila dikaitkan dengan usaha memajukan kehidupan bermasyarakat.Pada awalnya konsep dan istilah pembangunan lebih banyak dikaitkan dengan semua hal yang ada hubungannya dengan kemajuan material dan ekonomi, telah bergeser maknanya kearah yang lebih multi demensi.Oleh Karena itu hal yang berkaitan dengan pembangunan dapat dikaitkan dengan berbagai disiplin ilmu.

Dalam kaitan dengan tulisan ini istilah yang paling popular di Indonesia adalah konsep pembangunan yang tercantum dalam GBHN 1993 (Garis garis Besar Haluan Negara) yang menjelaskan konsep pembangunan nasional adalah konsep pembangunan manusia Indonesia seutuhnya dan masyarakat Indonesia seluruhnya, konsep pembangunan in mengandung arti bahwa pembangunan tidak hanya mengejar kemajuan lahiriah saja seperti kecukupan sandang ,pangan , perumahan ataupun kesehatan tetapi juga juga aspek batiniah, non fisik, seperti Pendidikan, rasa aman , kebebasan mengeluarkan pendapat, dan dipenuhinya rasa keadilan.Dengan demikian mengacu pada GBHN maka konsep pembangunan nasional Indonesia adalah rangkaian upaya perubahan dalam semua aspek kehidupan bangsa seperti aspek politik,ekonomi, social budaya,dan aspek aspek lain untuk mencapai kesejahteraan masyarakat.

Apabila ditelusuri dari beberapa literatur yang berkaitan dengan pembangunan ,akan dapat ditemukan berbagai pengertian pembangunan yang dikemukakan para ahli .Tetapi dari berbagai pengertian tersebut dapat ditarik titik temu atau persamaan dalam memberikan pengertian pembangunan. Sebagai misal pendapat Philips Roupp yang mengemukakan bawa pembangunan adalah perubahan dari sesuatu yang kurang berarti menjadi berarti (Development signifies change from something thougt to be less desirable to something thought to be more desirable)

SP Siagian memberikan definisi pembangunan sebagai satu usaha atau serangkaian usaha pertumbuhan dan perubahan yang terencana yang dilakukan secara sadar oleh bangsa, negara dan pemerintah menuju modernisasi dalam rangka pembinaan bangsa( nation building) (dalam Siagian 1985). Bintoro dan Mustopadijaya mengemukakan bahwa pembangunan adalah suatu orientasi dan kegiatan usaha yang tanpa akhir,proses pembangunan adalah merupakan proses perubahan social budaya yang akan menjadi proses yang dapat bergerak maju sangat tergantung kepada manusianya dan struktur social masyarakatnya dan tidak hanya sebagai usaha yang dikonsepkan oleh pemeritah saja tetapi sangat tergantung pada innerwill dari manusia dan masyarakatnya (Bintoro, 1983).

Menurut Todaro terkait dengan pengertian pembangunan, haruslah mempunyai 3 sasaran , yaitu:

1. pembangunan haruslah meningkatkan ketersediaan pangan, sandang , papan, kesehatan .

2. pembangunan haruslah meningkatkan taraf hidup, meningkatkanpendapatan, memperluas kesempatan kerja, pendidikan yang lebih baik,perhatian yang lebih besar kepada nilai nilai budaya dan kemanusiaan yang selain memperbaiki kesejahteraan tetapi juga meningkatkan harga diri sebagai individu dan bangsa.

3. memperluas pilihan ekonomi dan sosial yang tersedia bagi setiap orang dan bangsa sehingga terbebas dari perbudakan dan ketergantungan baik sebagai individu maupun negara terbebas dari ketergantungan pada negara lain. 
Dari beberapa pendapat para ahli dapatlah disimpulkan pengertian pembangunan nasional mengandung makna sebagai konsep yang bersifat dinamis dan multidimensional yang dilakukan secara sadar dan terus menerus serta sistematis, sehingga akan mempengaruhi semua aspek kehidupan manusia maupun bangsa dan negara, jadi tidak hanya diartikan secara ekonomi saja.Dengan dilaksanakannya pembangunan nasional maka akan terjadi peningkatan kemampuan individu disemua bidang kehidupan, seperti peningkatan Pendidikan yang lebih baik,peningkatan kemampuan memenuhi kebutuhan hidup, peningkatan kesempatan untuk memilih baik secara ekonomi ,social ataupun politik, peningkatan harga diri, Selain peningkatan kemampuan individu dalam negara, dengan pembangunan nasional akan terjadi peningkatan kemampuan negara disemua bidang kehidupan, kemampuan dan posisi tawar negara dihadapan negara lain,sehingga tidak akan terjadi ketergantungan pada negara lain.

Dalam pelaksanaan pembangunan di Indonesia, pemerintah sebagai penyelenggara negara berusaha melaksanakan pembangunan nasional dengan indikator indikator yang jelas dan terukur sehingga secara kuantitas dapat dilihat tingkat keberhasilan pembangunan nasional . Ukuran yang sering digunakan adalah dengan melihat tingkat pertumbuhan ekonomi negara, kemampuan negara dalam menekan inflasi yang kalau lebih dicermati akan tampak bahwa tingkat pertumbuhan ekonomi yang selalu dipertahankan Indonesia belum tentu dirasakan oleh semua warganegara diseluruh wilayah negara, karena pemerintah hanya fokus kepada tingkat pertumbuhan ekonomi saja tanpa memperhatikan pemerataan dari pertumbuhan ekonomi tersebut.

Sebagai gambaran makro ekonomi Indonesia, pemerintah mampu menjaga pertumbuhan ekonomi dikisaran 5,02\% dikwartal terakhir 2016 dan meningkat 5,1 dikwartal pertama 2017 dalam kondisi ekonomi dunia yang sedang sulit seperti saat ini. Namun secara mikro gambaran cerah seperti ini tidak selalu dirasakan pada semua lapisan masyarakat, banyak warga masyarakat yang tidak ikut merasakan hasil hasil pembangunan ekonomi meskipun mereka merupakan pelaku pembangunan.Dalam perjalanan sejarah dari era pemerintahan presiden Soekarno sampai dengan saat ini pemerintahan presiden Joko Widodo, pemerintah selalu berupaya untuk melaksanakan pembangunan nasional sesuai yang telah digariskan oleh Pembukaan Undang undang Dasar 1945.Namun demikian perbedaan kondisi negara dan tantangan yang dihadapi maka amanat yang jelas dalam Pembukaan UUD 1945 tidak bisa dengan mudah dicapai.

Pada tahun 2000 telah disepakati bersama dalam bentuk deklarasi yang ditanda tangani oleh 198 negara anggota PBB yang mencanangkan 8 target Pembangunan Milenium atau sering disebut Millenium Development Goals / MDGs yaitu yang terdiri(Undp, 2015a) :

1. Memberantas kemiskinan dan kelaparan.

2. Mewujudkan Pendidikan dasar.

3. Mendorong kesetaraan gender dan pemberdayaan perempuan.

4. Penurunan angka kematian anak.

5. Meningkatkan kesehatan ibu.

6. Menanggulangi dan memerangi HIV/AIDS, malaria dan penyakit menular lainnya.

7. Pelestarian lingkungan.

8. Mendorong pelaksanaan pembangunan berkelanjutan.

Pada September 2015 pada sidang umum PBB yang dihadiri 193 anggota PBB secara resmi menetapkan Agenda Pembangunan Berkelanjutan atau SDGs Sustainable Development Goals, sebagai kesepakatan pembangunan global termasuk wakil presiden Jusuf Kalla turut mengesahkan Agenda Pembangunan Berkelanjutan 2030 untuk Indonesia.Mulai tahun 2016 secara resmi tujuan Pembangunan Berkelanjutan (SDGs)2015-2030 menggantikan tujuan Millenium Development Goals(MDGs) 2000-2015. SDGs berisikan tujuan yang disepakati dan berlaku untuk semua bangsa tanpa terkecuali. 
SDGs berisi 17 tujuan /goals dan 169 target yang menggambarkan sasaran dan lingkup agenda pembangunanglobal yang inklusif multidimensi, adapun 17 tujuan tsb antara lain(Undp, 2015b):

1. Tanpa kemiskinan/no poverty

2. Tanpa kelaparan/ zero hunger

3. Kesehatan yang baik dan kesejahteraan/good health and well-being

4. Pendidikan berkualitas/quality education

5. Kesetaraan gender/gender equality

6. Air bersih dan sanitasi/ clean water and sanitation

7. Energi bersih dan terjangkau/ affordable and clean energy

8. Pertumbuhan ekonomi dan pekerjaan yang layak/ decent work and economic growth

9. Industri, inovasi dan infrastruktur/ industry, innovation and infrastructure

10. Mengurangi kesenjangan/ reduce inequality

11. Keberlanjutan kota dan komunitas/sustainable cities and communities

12. Konsumsi dan produksi bertanggung jawab/ responsible consumption and production

13. Aksi terhadap iklim/ climate action

14. Kehidupan bawah laut/ life below water

15. Kehidupan di darat/life on land

16. Institusi peradilan yang /peace, justice and strong institution

17. Kemitraan untuk mencapai tujuan/ partnerships for the goals

Tujuan Pembangunan Berkelanjutan (TPB)/Sustainable Development Goals (SDGs) yang dideklarasikan tsb menjadi arahan semua negara dengan tidak terkecuali dalam menjalankan pembangunan .Setiap negara anggota Perserikatan Bangsa Bangsa(PBB) termasuk Indonesia menyepakati komitmen global Tujuan Pembangunan Berkelanjutan.

\section{2 Konsep dan teori Gender}

Gender berasal dari Bahasa latin genus yang berarti jenis atau tipe. Gender merupakan ciri ciri peran dan tanggung jawab yang dibebankan pada perempuan ataupun laki laki secara social bukan dari kodrat ataupun pemberian Tuhan. Konsep dasar gender merupakan hasil konstruksi social yang diciptakan manusia dan masyarakatnya, sifatnya tidak tetap, berubah ubah dan dapat dipertukarkan ataupun dialihkan menurut waktu, tempat dan budaya setempat dari satu jenis kelamin kejenis kelamin yang lain.

Konsep gender juga termasuk ciri dan karakteristik yang diciptakan oleh keluarga, ataupun masyarakat setempat sesuai nilai nilai budaya yang dianut oleh masyarakat tersebut. Misalnya pada umumnya pekerjaan memasak, mencuci atau mengasuh anak adalah pekerjaan perempuan disatu masyarakat tertentu, tetapi tidak demikian di masyarakat yang lain .Perempuan dikenal lemah lembut, emosional sedangkan laki laki dikenal perkasa, kuat dan sangat rasional atau dikenal istilah feminin dan maskulin. Istilah gender pertama kali diperkenalkan oleh Robert Stoller pada 1968 untuk memisahkan pencirian manusia yang didasari pada pendifinisian yang bersifat social budaya dengan ciri ciri fisik biologis.

Pembahasan tentang gender mulai berkembang hampir bersamaan dengan timbulnya gerakan gerakan feminism di Eropa dan Amerika yang menuntut kesamaan perlakuan antara laki laki dan perempuan yang menimbulkan istilah 50:50 ( fifty-fifty) yang diartikan sebagai perfect equality,kesamaan yang sempurna antara laki laki dan perempuan. Hal seperti ini sangat sulit untuk diwujudkan karena berbagai hambatan baik dari nilai nilai agama, nilai nilai sosial ataupun budaya setempat.Gender sering disalah artikan sebagai perbedaan yang diakibatkan perbedaan jenis kelamin,. Hal inilah yang juga menimbulkan perbedaan perlakuan karena perbedaan jenis kelamin yang memang sudah dibawa sejak lahir.Gender adalah suatu konstruksi sosial yang dibuat oleh masyarakat untuk menunjukkan perbedaanperan ,fungsi dan tanggung jawab antara laki laki dan perempuan yang merupakan hasil konstruksi social atau bentukan budaya setempat.jadi gender 
akan sangat dimungkinkan dirubah oleh masyarakat meskipun membutuhkan waktu yang lama ,berbeda dengan jenis kelamin yang tidak dapat dirubah memeng sudah dibawa sejak lahir, dan tidak berbeda dari satu tempat dengan tempat yang lain.

Pelarangan diskriminasi atas jenis kelamin/gender telah dinyatakan di dalam seluruh instrumen di bawah Bill of Rights, yang terdiri dari Deklarasi Universal HAM (Universal Declaration of Human Rights/UDHR),Kovenan Internasional tentang Hak Sipil dan Politik (International Covenant on Civil an Political Rights/ICCPR) dan Kovenan Internasional tentang Hak Ekonomi, Sosial dan Budaya (International Covenant on Economic, Social and Cultural Rights/ICESCR).

UDHR, pasal 2 :

"Setiap orang berhak atas hak dan kebebasanyang dinyatakan dalam Deklarasi ini,tanpa pembedaan atas dasar apapun seperti ras, warna kulit, jenis kelamin, bahasa, agama, politik atau pendapat, asal usul kebangsaan atau sosial, properti, kelahiran atau status lainnya ....."

ICCPR, Pasal 2 paragraf (1) :

"Setiap Negara Peserta Perjanjian ini menghormati dan menjamin seluruh individu di dalam wilayahnya dan yang patuh pada jurisdiksinya hak yang diakui di dalam Perjanjian ini tanpa pembedaan atas dasar apapun, seperti ras, warna kulit, jenis kelamin, bahasa, agama, politik etau pendapat, asal usul kebangsaan atau properti, kelahiran atau status lainnya.

ICESCR, Pasal 3 :

"Negara Peserta Perjanjian ini menjamin hak setara laki laki dan perempuan untuk menikmati seluruh hak ekonomi, sosial dan budaya yang ditetapkan di dalam Perjanjian ini.

Pada 1979 PBB secara resmi mengadopsi sebuah instrumen hukum yang secara khusus terkait dengan hak perempuan, yaitu Konvensi Penghapusan Segala Bentuk Diskriminasi terhadap Prempuan (Convention on the Elimination of All Forms of Discrimination against Women (CEDAW).Konvensi ini menjabarkan definisi diskriminasi berbasis jenis kelamin meliputi :

-Secara sengaja maupun tidak disengaja merugikan kaum perempuan;

- tindakan masyarakat mencegah untuk mengakui hak perempuan diranah privat maupun di ranah publik;

- Mencegah perempuan menikmati HAMnya dan kebebasan fundamental yang menjadi haknya

CEDAW berusaha memberikan perlindungan kepada perempuan dari diskriminasi baik di ranah politik, ekonomi maupun sosial budaya.CEDAW juga memberikan landasan dan mewajibkan negara negara peserta utuk menghapus diskriminasi dengan cara mengadopsi undang undang yang melarang perlakuan yang diskriminatif, mencegah terjadinya tindakan yang diskriminatif, melindungi perempuan dari perlakuan diskriminatif dari aktor non negara baik yang berupa individu maupun organisasi ataupun perusahaan(KONTRAS, 2006).

Walaupun dalam UUD 1945 tidak menyebut pelarangan diskriminatif berbasis gender tetapi UUD 1945 melarang semua diskriminasi atas dasar apapun.Lebih lanjut dalam UU No.39 Tahun 1999 tentang HAM terdapat bagian khusus yang membahas hak perempuan, yang mengakui hak perempuan sebagai hak asasi manusia (pasal 45),jaminan atas hak perempuan untuk keterwakilan di seluruh cabang pemerintahan (pasal 46), hak perempuan atas pendidikan (pasal 48 ), hak perempuan untuk bekerja dan berada ditempat kerja( pasal 49 ).Pemerintah Indonesia telah membentuk Komisi Nasional Anti Kekerasan terhadap Perempuan ( Komnas Perempuan) sebagai bagian dari lembaga HAM nasional sejak tahun 1998 dan juga Undang Undang KDRT sejak 2004.Meskipun banyak hal yang sudah dicapai di sektor hukum tetapi masih banyak perlakuan diskriminatif terhadap perempuan, seperti kekerasan domestik dalam rumah tangga, perdagangan menusia dimana perempuan dan anak perempuan merupakan mayoritas korban, sunat perempuan.

\section{3. Perspektif gender dalam Pembangunan Nasional}

Sesuai dengan target yang dicanangkan bersama dalam SDGs terkait tujuan ke 5, yaitu kesetaraan gender dan pemberdayaan perempuan/anak perempuan maka setiap negara sangat 
diharapkan dalam melaksanakan semua kebijakan dan pembangunan dalam negara diharapkan memperhatikan kesetaraan gender dan memberdayakan kaum perempuan. Pemerintah Indonesia sejalan dengan hampir semua tujuan yang dicanangkan dalam SDGs, yang dicantumkan dalam RPJMN 2015-2019.Pada saat penanda tanganan kesepakatan SDGs/Tujuan Pembangunan Berkelanjutan/TPB ,Indonesia yang diwakili oleh wakil presiden Jusuf Kalla menyampaikan bahwa poin poin yang tercantum dalam SDGs dapat diselaraskan dengan agenda dan rencana Pembangunan Nasional.Indonesia mempunyai prioritas pembangunan yang tercantum dalam Rencana Pembangunaan Jangka Menengah (RPJMN) 2015-2019 yang menjadi arah dalam melaksanakan pembangunan nasional, sedangkan SDGs/TPB merupakan komitmen internasional untuk meningkatkan kualitas hidup dari satu generasi ke generasi berikutnya.Oleh karena itu SDGs/TPB harus diselaraskan dan diharmonisasikan dengan tujuan Pembangunan Nasional, maka SDGs/TPB juga menjadi acuan bersama dalam menjalankan agenda dan rencana Pembangunan Nasional baik di pusat ataupun didaerah.

Prioritas pembangunan nasional jangka menengah yang sudah dicantumkan dalam RPJMN 2015-2019 meskipun disusun pada 2014 ternyata apa yang menjadi target SDGs/TPB banyak yang sudah tercantum dalam prioritas pembangunan RPJMN.Bila dilihat dari Pilar yang ada dalam SDGs/TPB maka tampak bahwa sudah banyak target yang menjadi sasaran yang akan diwujudkan dalam SDGs banyak yang sudah di agendakan dalam RPJMN, seperti :

- $\quad$ Pilar Ekonomi (meliputi tujuan 7,8,9,10,17) , target global ada 54, target RPJMN 30, prioritas Nasional mencakup, kedaulatan energi, akselerasi pertumbuhan ekonomi nasional,peningkatan daya saing tenaga kerja, pemerataan pembangunan antar wilayah, pelaksanaan politik LN bebas aktif

- Pilar Sosial(meliputi tujuan 1,2,3,4,5), target global 47, target RPJMN 27, prioritas nasional mencakup , penanggulangan kemiskinan, peningkatan kesejahteraan masyarakat, peningkatan kedaulatan pangan, pelaksanaan program Indonesia pintar dan Indonesia sehat, melindungi anak perempuan dan kelompok marjinal.

- Pilar Lingkungan (meliputi tujuan 6,11,12,13,14,15),target SDGs/TPB 56, target RPJMN 31,prioritas nasional mencakup, ketahanan air, membangun perumahan dan kawasan pemukiman, penanganan perubahan iklim dan penyediaan informasi iklim dan kebencanaan serta mengurangi emisi karbon, pelestarian SDA, lingkungan hidup dan pengelolaan bencana, rencana aksi dan strategi keanekaragaman hayati Indonesia.

- Pilar Hukum dan Tata Kelola (meliputi tujuan 16) target global ada 12, target RPJMN

Dengan mengacu pada Perpres No.2 Tahun 2015 tentang RPJMN tahun 2015-2019 maka disahkan Perpres No.59 Tahun 2017 tentang Pelaksanaan Pencapaian Tujuan Pembangunan Berkelanjuta(Mada, n.d.).Terkait dengan tujuan 5 dari SDGs yang ditegaskan dalam Lampiran Perpres No.59 Tahun 2017. Tujuan global dari SDGs adalah mencapai kesetaraan gender dan memberdayakan perempuan, dan sasaran global yang akan diwujudkan adalah :

1. Mengakhiri segala bentuk diskriminasiterhadap kaum perempuan dimanapun

2. enghilangkan segala bentuk kekerasan terhadap perempuan diruang publik dan privat, termasuk perdagangan manusia dan eksploitasi seksual, serta berbagai bentuk eksploitasi lainnya.

3. Menghilangkan semua praktek berbahaya, seperti pernikahan anak, pernikahan dini dan paksa, serta sunat perempuan.

4. Menjamin partisipasi penuh dan efektif, dan kesempatan yang sama bagi perempuan untuk memimpin di semau tingkat pengambilan keputusan dalam kehidupan politik, ekonomi, dan masyarakat.

5. Menjamin akses universal terhadap kesehatan seksual dan reproduksi, dan hak reproduksi seperti yang disepakati sesuai dengan Programme of Action of the International Conference 
on Population and Development and the Beijing Platform serta dokumen dokumen hasi review dari konferensi tsb.

Dari sasaran global tujuan ke5 yaitu mencapai kesetaraan gender dan pemberdayaan perempuan tersebut tampak bahwa Pembangunan Nasional seperti yang dituangkan dalam Sasaran Nasional RPJMN 2015-2019 terdapat kesesuaian .Adapun Sasaran Nasional RPJMN 2015-2019 sbb:

1. Meningkatnya jumlah kebijakan yang responsif gender mendukung pemberdayaan perempuan pada tahun 2019

2. -Menurunnya pravalensi kasus kekerasan terhadap anak perempuan

-Meningkatnya layanan komprihensif terhadap kasus kekerasan terhadap perempuan

3. -Meningkatnya median usia kawin pertama perempuan( pendewasaan usia kawin pertama)

-Meningkatnya APK/Angka Partisipasi Kasar SMP/SMA/MA/sederajat pada tahun 2019

4. -Meningkatnya keterwakilan perempuan di DPR

5. -Menurunnya kebutuhan ber KB

- Meningkatnya penetahuan dan pemahaman tentang metode kontrasepsi modern

- Tersedianya regulasi yang menjamin perempuan untuk mendapatkan pelayanan, informasi, dan pendidikan terkait keluarga berencana dan kesehatan reproduksi.

Adapun dalam pelaksanaan Sasaran Nasional tersebut Pemerintah melibatkan hamoir semua instansi baik pusat maupun daerah yang meliputi antara lain :

Kementerian Koordinator Bidang Pembangunan Manusia dan Kebudayaan, Kementrian Perencanaan Pembangunan Nasional/Bappenas, Kementrian Keuangan, Kementrian Pemberdayaan Perempuan ddan Perlindungan Anak, Kementrian Dalam Negeri, Kementrian Pendayagunaan Aparatur Negara dan Reformasi Birokrasi, Kementrian Ketenagakerjaan, Kementrian Koperasi dan Usaha Kecil dan Menengah, Komisi Pemilu, Badan Kepegawaian Negara, Pemerintah Daerah Provinsi, Penerintah Daerah Kabupaten/Kota.

Meskipun Agenda SDGs sampai dengan tahun 2030, tetapi pemerintah Indonesia sudah mengharmonisasikan dan menyelaraskan jalannya Pembangunan Nasional dengan komitmen global yang sudah disepakati bersama terkait dengan pencapaian kesetaraan gender dan pemberdayaan perempuan dengan berbagai instrumen dan upaya untuk mewujudkannya.

\section{KESIMPULAN}

Dalam pelaksanaan Pembangunan Nasional ,pemerintah sudah berupaya mewujudkan kesetaraan gender dan pemberdayaan perempuan dalam upaya mewujudkan tujuan dan cita cita bangsa dan negara seperti yang sudah diamanatkan dalam Pembukaan UUD 1945. Berbagai instrumen dan aturan yang menunjang sudah dibuat dan diratifikasi demi mewujudkan keadilan gender.

\section{DAFTAR PUSTAKA}

Bintoro, M. (1983). teori dan startegi Pembangunan Nasional (1st ed.). jakarta: Gunung Agung. KONTRAS. (2006). www.kontras.org.

Mada, U. G. (n.d.). www.ugm.ac.id.

Undp. (2015a). WWW.id.undp.org.

Undp. (2015b). www.undp.org. 